\title{
Newly identified helper bacteria stimulate ectomycorrhizal formation in Populus
}

\author{
Jessy L. Labbé *, David J. Weston, Nora Dunkirk, Dale A. Pelletier and Gerald A. Tuskan
}

Biosciences Division, Oak Ridge National Laboratory, Oak Ridge, TN, USA

\section{Edited by:}

Brigitte Mauch-Mani, Université de Neuchâtel, Switzerland

Reviewed by:

Dale Ronald Walters, Scottish Agricultural College, Scotland Ana Pineda, Wageningen University, Netherlands

*Correspondence:

Jessy L. Labbé, Biosciences

Division, Oak Ridge National

Laboratory, P. O. Box 2008

MS-6407, Oak Ridge, TN

37831-6407, USA

e-mail: labbejj@ornl.gov
Mycorrhiza helper bacteria (MHB) are known to increase host root colonization by mycorrhizal fungi but the molecular mechanisms and potential tripartite interactions are poorly understood. Through an effort to study Populus microbiome, we isolated 21 Pseudomonas strains from native Populus deltoides roots. These bacterial isolates were characterized and screened for MHB effectiveness on the Populus-Laccaria system. Two additional Pseudomonas strains (i.e., Pf-5 and BBc6R8) from existing collections were included for comparative purposes. We analyzed the effect of co-cultivation of these 23 individual Pseudomonas strains on Laccaria bicolor "S238N" growth rate, mycelial architecture and transcriptional changes. Nineteen of the 23 Pseudomonas strains tested had positive effects on L. bicolor S238N growth, as well as on mycelial architecture, with strains GM41 and GM18 having the most significant effect. Four of seven L. bicolor reporter genes, Tra1, Tectonin2, Gcn5, and Cipc1, thought to be regulated during the interaction with $\mathrm{MHB}$ strain BBc6R8, were induced or repressed, while interacting with Pseudomonas strains GM17, GM33, GM41, GM48, Pf-5, and BBc6R8. Strain GM41 promoted the highest roots colonization across three Populus species but most notably in $P$. deltoides, which is otherwise poorly colonized by L. bicolor. Here we report novel MHB strains isolated from native Populus that improve L. bicolor root colonization on Populus. This tripartite relationship could be exploited for Populus species/genotypes nursery production as a means of improving establishment and survival in marginal lands.

Keywords: mycorrhiza helper bacteria, mycorrhizal fungi, Laccaria bicolor, mutualistic interactions, fungalbacterial-Populus interactions, Populus rhizosphere, soil microbiology

\section{INTRODUCTION}

The majority of terrestrial plants are known to form specialized mycorrhizal structures with symbiotic fungi (Read et al., 2000). This mycorrhizal symbiosis enhances plant growth and has been actively studied for its potential use in agriculture and forestry applications. Understanding the ecology and physiology of the association and how to control its establishment and stability has become a key focus in basic and applied plant sciences. In addition, several researchers have noted that the establishment and functioning of mycorrhizal symbioses can be positively influenced by certain bacterial strains that have been categorized as Mycorrhiza Helper Bacteria (MHB) (Garbaye, 1994; Frey-Klett et al., 2007).

Known MHB strains include a variety of Gram-negative (Barea et al., 1998; Founoune et al., 2002b; Frey-klett et al., 2005) and Gram-positive (Budi et al., 1999; Poole et al., 2001; Schrey et al., 2005) bacterial species. Because of their potential to increase plant nutrition and health, the use of MHB in low-input agriculture and forestry has been addressed in several investigations (Duponnois et al., 1993; Barea et al., 1998; Becker et al., 1999; Schrey et al., 2005). The definition of the MHB concept is evolving, encompassing either the type of mycorrhizal symbiosis or the taxonomy of the MHB strains. To date, many bacterial strains have been reported to promote either endo- or ectomycorrhizal symbioses (Garbaye, 1994; Barea et al., 2002; Johannsson et al., 2004; Artursson et al., 2006; Duponnois, 2006; Pivato et al., 2009) and various plant models have been used to study the MHB effect (Garbaye, 1994; Schrey et al., 2005; Duponnois and Kisa, 2006; Pivato et al., 2009). There are, however, no reports on the characterization of MHB strains isolated from a single host species and then subsequently re-inoculated on that host to determine if there is a beneficial response. In this study we used Populus spp. (poplar, cottonwood, aspen) to test these relationships.

Populus is cultivated worldwide for pulp and paper, veneer, packing material, engineered wood products (e.g., oriented strand board), lumber, and has recently emerged as the preeminent fast-growing woody crop for bioenergy research (Tuskan and Walsh, 2001; Jansson and Douglas, 2007; Sannigrahi and Ragauskas, 2010). Populus can be grown on economically marginal agricultural land thereby minimizing the competition between food and fuel production (Bradshaw et al., 2000; Tuskan et al., 2006; Sannigrahi and Ragauskas, 2010). Moreover, Populus is known to associate with a wide variety of root symbiotic microbes. Populus is also one of the few plants known to be colonized by both endo- and ectomycorrhizal fungi, making it a unique model system for the study of interactions between plants and microorganisms (Martin et al., 2004). To date, the study of the role of bacterial associates of Populus has been limited 
to plant-growth-promoting studies or phytoremediation research (Moore et al., 2006; Taghavi et al., 2010; Weston et al., 2012), with little attention given to their potential role as MHB facilitating Populus-fungal interactions.

As part of a recent effort characterizing microbial rhizosphere communities of native Populus deltoides (Gottel et al., 2011), a collection of Populus-associated bacterial isolates comprising seven classes and 89 genera, as determined by $16 \mathrm{~S}$ rDNA sequence analysis, has been established (Brown et al., 2012). A subset of 43 isolates has been genome sequenced, of which only 21 are Pseudomonas related strains, which were selected here for comparison with the reference helper Pseudomonas BBc6R8 (Deveau et al., 2007). Thus, we investigated the effect of potential MHB bacterial isolates from native $P$. deltoides rhizosphere on the ectomycorrhizal Populus-Laccaria bicolor interaction. The objectives of this work were to: (1) determine whether the $P$. deltoidesderived bacterial isolates have any effect on $L$. bicolor mycelial architecture and growth, (2) assess the expression level of seven target genes in L. bicolor shown to be regulated by the $\mathrm{MHB}$ strain BBc6R8 (Deveau et al., 2007), (3) determine whether the diverse fungus-bacteria combinations have any effect on Populus root architecture and (4) characterize ectomycorrhizal formation across selected combinations of MHB strains.

\section{MATERIALS AND METHODS MICROORGANISMS, STRAINS, AND CULTURE CONDITIONS}

The symbiotic fungus Laccaria bicolor (Maire) P.D. Orton is a member of the Hydnangiaceae (Basidiomycota, Agaricomycotina, Agaricomycetes, Agaricomycetidae, Agaricales), a large family of ectomycorrhizal and saprotrophic basidiomycetes. A subculture of this strain, S238-O, was transferred to the INRA-Nancy in 1980 and renamed S238N (Di Battista et al., 1996). The genomic sequence of the monokaryotic mycelia S238N-H82 was subsequently published (Martin et al., 2008). The dikaryotic mycelium of L. bicolor S238N used in this study was grown and maintained in Petri dishes containing Pachlewski agar medium P5 (Di Battista et al., 1996) and incubated at $25^{\circ} \mathrm{C}$ for 3 week.

The Pseudomonas fluorescens strain BBc6R8 was isolated from L. bicolor S238N associated with Douglas-fir (Pseudotsuga menziesii) roots (Duponnois and Garbaye, 1991). This strain has been categorized as MHB as it increases mycorrhization and/or growth of the fungus (Duponnois and Garbaye, 1991; Frey-Klett et al., 1997; Deveau et al., 2007); it was used as a positive control in our experiments. The specific strain, BBc6R8, used in this study is a spontaneous rifampicin resistant mutant, but phenotypically conforms to the parental strain BBc6. The Pseudomonas protegens Pf-5 (previously P. fluorescens Pf-5) ATCC BAA-477 (Howell and Stipanovic, 1978; Paulsen et al., 2005) was purchased from American Type Culture Collection (Manassas, VA), is a wellstudied biocontrol strain (Loper et al., 2007) and was included as a negative control.

Pseudomonas sp. strains GM16, GM17, GM18, GM21, GM24, GM25, GM30, GM33, GM41, GM48, GM49, GM50, GM55, GM60, GM67, GM74, GM78, GM79, GM80, GM84, and GM102, were isolated from $P$. deltoides rhizosphere or surface sterilized roots of mature native trees collected in central Tennessee (Gottel et al., 2011). All the bacterial strains were maintained at $-80^{\circ} \mathrm{C}$ in Luria-Bertani (LB) medium (Sambrook et al., 1989) with 20\% glycerol.

\section{BACTERIAL-FUNGAL PAIRWISE ASSAYS AND MORPHOLOGICAL MEASUREMENTS}

From maintenance cultures, each of the bacterial strains were subcultured on $10 \%$ TSA [i.e., $15 \mathrm{~g} \mathrm{l}^{-1}$ of agar, $3 \mathrm{~g} \mathrm{l}^{-1}$ tryptic soy broth (Difco, Detroit, MI)] plates at $25^{\circ} \mathrm{C}$ for $65 \mathrm{~h}$ to prepare the bacterial inoculum for the in vitro bioassay. Then, three to four colonies were picked and suspended in $2 \mathrm{ml}$ of sterile deionized water before re-distribution on to $10 \%$ TSA medium. After $48 \mathrm{~h}$ of growth at $25^{\circ} \mathrm{C}$, the bacteria were harvested and centrifuged at $3300 \mathrm{~g}$ for $10 \mathrm{~min}$. The pellet was washed once and then diluted in deionized water in order to obtain a suspension with $\mathrm{A} 600_{n m} 0.7$ (ca. $10^{9} \mathrm{cfu} \mathrm{ml}^{-1}$ ).

In vitro pairwise assays were performed as reported by Deveau et al. (2007), on 150-mm Petri dishes containing $25 \mathrm{ml}$ of modified Pachlewski medium (P5, i.e., P20Th ${ }^{-}$; $0.5 \mathrm{~g}$ tartrate, $1 \mathrm{~g}$ $\mathrm{KH}_{2} \mathrm{PO}_{4}, 0.5 \mathrm{~g} \mathrm{MgSO}_{4}, 1 \mathrm{~g}$ glucose, $1 \mathrm{ml} 1 / 10$ diluted Kanieltra micronutrient solution and $20 \mathrm{~g} \mathrm{l}^{-1}$ agar, $\mathrm{pH}$ 5.5). A $10-\mathrm{mm}$ plug of L. bicolor S238N mycelium was cut out from the edge of a colony grown on P5 medium and transferred into the center of a $\mathrm{P}_{20 \mathrm{Th}^{-}}$plate. Four 10- $\mu$ l droplets of sterile deionized water (control) or bacterial suspension (treatment) were distributed diametrically opposite at $1.75 \mathrm{~cm}$ from the center of the fungal plug. Plates were sealed with electric tape and incubated at $10^{\circ} \mathrm{C}$ in the dark. The diameter of the fungal colony was measured every fourth day from day 12 to 32 after the addition of water or bacterial suspensions, with seven replicates per treatment. Architecture of the fungal mycelium was analyzed at three key stages: before contact between the mycelium and the bacteria $(14 \mathrm{~d})$, at contact time (ca. 16 d) and after an extended contact period (21 d). Three biological replicates (independent experiments) per treatment were performed. For each replicate, two photographs were taken using a Zeiss MicroImaging steREO Discovery V.8 (40x magnification) equipped with a Color-View System AxioCam ICc1 camera (Zeiss, Thornwood, NY). The number of apices per microscopic field $\left(3.5 \mathrm{~mm}^{2}\right)$, branching angles, branching densities (number of ramifications divided by the number of apices) and curvature of hyphae were measured on each photograph using the AxioVision 4.8 imaging processing software (Zeiss, Thornwood, NY). The effect of the bacterial treatment on the growth and architecture of the fungal mycelium was determined using analysis of variance (ANOVA) at a $p$-value of 0.05 . The Least Significant Difference (LSD) test was used for pairwise comparison after ANOVA. The R statistical package 2.12.1 was used for all statistical analyses (R Foundation for Statistical Computing, Vienna, Austria).

\section{GENE EXPRESSION ANALYSIS IN L. BICOLOR}

To verify BBc6R8 effect on L. bicolor gene expression (Deveau et al., 2007), and to compare responses among bacterial strains, we analyzed the expression of seven target/reporter genes from L. bicolor $\mathrm{S} 238 \mathrm{~N}$ mycelium in pairwise assays. Mycelium was collected in triplicate before contact between the fungus and bacteria (14d) and after an extended contact period (21 d). RNA was extracted using the Spectrum Plant Total RNA Kit 
(Sigma-Aldrich, St. Louis, MO) following the manufacturer's recommendations. The quality of the RNA was checked by RNAse-free 1\% agarose electrophoresis. The cDNAs were synthesized using the SuperScript III First-Strand Synthesis System kit (Invitrogen-Live Technologies, Grand Island, NY). Real-time PCR analyses were performed using primers for seven up- and/or down-regulated genes (i.e., Cipc1, Tectonin2, Tra1, Gcn5, Ada3, Fox2, and Spt3) and two non-regulated genes (i.e., Lb17E10 and trehalose phosphorylase) as controls. Data normalization was as described by Deveau et al. (2007). Real-Time PCRs were carried out on the StepOne RT-PCR system using the SYBR Green DNA detection dye (Applied Biosystems, Foster City, CA). A negative control reaction that did not contain DNA template ("water blanks") was run for each primer pair to demonstrate absence of PCR products in amplifications of cDNA from fungal tissues. For data analysis, the geometric mean of the three biological replicates for each condition was calculated. The PCR efficiency was checked and fold differences were calculated using the $\Delta \Delta \mathrm{Ct}$ method (Livak and Schmittgen, 2001).

\section{PLANT MATERIAL AND CO-CULTURE EXPERIMENTS}

In vitro experiments were performed with micropropagated Populus clones "717-1B4" (female, P. tremula $\times$ alba), "93-968" (female, P. trichocarpa), and "D-124” (male, P. deltoides). Fresh, actively growing shoots from plants grown in a greenhouse were used as propagation materials and were established in $100 \mathrm{ml}$ of MS medium with micro and macronutrients, vitamins and glycine (Murashige and Skoog, Sigma-Aldrich, St. Louis, MO) supplemented with $1 \%$ (w/v) sucrose, $0.5 \mathrm{~g}$ MES hydrate (SigmaAldrich) and solidified with $0.8 \%(\mathrm{w} / \mathrm{v})$ agar and $\mathrm{pH}$ adjusted to 5.7. Explants were established in culture after surface-sterilization [i.e., $5 \mathrm{~min}$ in $1 \%(\mathrm{v} / \mathrm{v})$ Tween-20 solution, $1 \mathrm{~min}$ in $70 \%(\mathrm{v} / \mathrm{v})$ ethanol, $15 \mathrm{~min}$ in $10 \%(\mathrm{v} / \mathrm{v})$ bleach solution and then triple rinsed for $5 \mathrm{~min}$ in sterile water]. The plants were maintained in Magenta boxes (GA-7) and were cultivated in a tissue culture growth room at $25^{\circ} \mathrm{C}$ with a 24 -h photoperiod under fluorescence tubes (cool white, $95 \mathrm{~W}, \mathrm{~F} 96 \mathrm{~T} 12 / \mathrm{CW} / \mathrm{HO} / \mathrm{SS}$, Sylvania) at an intensity of $70 \mu \mathrm{mol} \mathrm{m} \mathrm{m}^{-2} \mathrm{~s}^{-1}$. Plants were multiplied every 6-8 weeks to maintain vigorous stock plants (Kang et al., 2009). Plant materials were simultaneously prepared for in vitro coculture experiments. In order to synchronize rhizogenesis, stem cuttings from the in vitro stock plants were pre-cultured on MS medium containing $2 \mathrm{mg}^{-1}$ indole butyric acid for 1 week. Rooted cuttings were then transferred to vertically arranged $12 \times$ $12 \mathrm{~cm}$ Petri dishes half covered with a $6 \times 6 \mathrm{~cm}$ cellophane membrane and containing sugar-minus Pachlewski medium P20Th(Deveau et al., 2007). These rooted cutting were inoculated or not (control) according to the following treatments-bacteria alone (BBc6R8, GM17, GM18, GM30 or GM41), fungus alone (L. bicolor $\mathrm{S} 238 \mathrm{~N}$ ) or pairwise combinations of bacteria and fungus. Bacterial and fungal inocula were synchronously prepared for the assays. Three 10- $\mu 1$ droplets of sterile deionized water (control) or bacterial suspension or three 10-mm-fungal plugs were horizontally distributed at $1.75 \mathrm{~cm}$ from the root system. In the bacterial-fungal treatment, bacterial droplets were vertically distributed at $0.6 \mathrm{~cm}$ from the fungal plugs that were spaced of $0.6 \mathrm{~cm}$ and vertically distributed at $1.75 \mathrm{~cm}$ from the root system.
Plates were sealed with tape on the upper and lower sides and with a gas permeable cover on both lateral sides. Sterile dental cotton was placed at the bottom of the plate for attenuating moisture. Plant co-cultures were arranged vertically and the lower part of the dish was covered with a small black plastic bag to prevent light from reaching microbes and roots. The co-cultures were kept in the same environmental conditions as the in vitro plant stock above. Quantification of the number of secondary roots and their length at 14 and 31 days post-inoculation (DPI) were performed using WinRHIZO and Photoshop software. The effect of the treatment on the number and length of the secondary roots was determined using ANOVA at a $p$-value of 0.05 .

Greenhouse experiments were performed with the same Populus clones listed above. Surface-sterilized-internode cuttings of each clone from plants grown in a greenhouse were rooted and individually simultaneously inoculated in 164-ml leach tubes containing a mixture of fungal inoculum $(1: 9, \mathrm{v}: \mathrm{v})$ and autoclaved peat-vermiculite $(1: 1, \mathrm{v}: \mathrm{v})$. Solid inoculum was prepared in 1-1 glass jars containing $800 \mathrm{ml}$ autoclaved peat-vermiculite mixture (1:1, v:v) moistened with $650 \mathrm{ml}$ liquid Pachlewski medium, inoculated with plugs from an agar culture and incubated for 6 weeks at $25^{\circ} \mathrm{C}$ (Duponnois and Garbaye, 1991). Bacterial inocula for BBc6R8, GM17, GM18, GM30, and GM41 were prepared as described by Frey-Klett et al. (1997). The absorbance of each bacterial suspension at $600 \mathrm{~nm}$ was adjusted to 1 in $0.1 \mathrm{~mol} \mathrm{l}^{-1} \mathrm{MgSO}_{4}$ buffer; then the suspensions were diluted 10 times. Five $\mathrm{ml}$ of each bacterial suspension $\left(10^{7} \mathrm{CFU} \mathrm{ml}{ }^{-1}\right)$ were distributed on the agar surface immediately after planting; the controls without bacteria received only $5 \mathrm{ml}$ of $0.1 \mathrm{~mol}$ $\mathrm{I}^{-1} \mathrm{MgSO}_{4}$ buffer. One cutting was grown per container. The containers were arranged in trays holding 12 containers (4 replicates per treatment). One tray was inoculated for each bacterial isolate. The control treatments-Populus clone-L. bicolor and Populus clone alone-were contained in three trays (one Populus clone per tray). In order to control environmental heterogeneity of the greenhouse, the trays were placed at random on two tables and were re-distributed weekly according to a circular permutation. Inoculated and control cuttings were grown for 12 weeks in the greenhouse at $20-25^{\circ} \mathrm{C}$, photoperiod $12 \mathrm{~h}$ during fall. Cuttings were watered twice daily with sterile water and received a weekly nutrient application as described in Frey-Klett et al. (1997). Twelve weeks after inoculation, the proportion of short roots forming mycorrhizae was determined by randomly examining 100 short roots per plantlet. Each root system was rinsed with sterile water, cut in 1-cm pieces and analyzed under a stereomicroscope. L. bicolor ectomycorrhizae were identified morphologically. The rinse water for each plant was recovered and $1 \mathrm{ml}$ used to re-inoculate five LB plates (Sambrook et al., 1989) at $25^{\circ} \mathrm{C}$ for $48 \mathrm{~h}$ in order to check the presence of the bacterial inoculum.

An individual bacterial colony was used to inoculate $40 \mathrm{ml}$ liquid LB medium (Sambrook et al., 1989) at $25^{\circ} \mathrm{C}$ for $24 \mathrm{~h}$. Then, bacterial DNA was isolated according to the QIAamp DNA Mini Kit protocol (QIAGEN, Valencia, CA). The 16S rDNAs were amplified by PCR with the primers fD1 and rD1 (Weisburg et al., 1991) and sequenced on an ABI 3730XL sequencer following the Applied Biosystems BigDye v.3.0 sequencing protocol. The 
16S rDNA sequences were analyzed using Sequencher 5.0 software (Gene Code Corporation, Ann Arbor, MI). The presence of the bacterial inocula at 12 weeks was confirmed by complete match of the $16 \mathrm{~S}$ rDNA sequences performed at the beginning and the end of the experiment. The percentage of mycorrhizal colonization was transformed using an arcsine $\sqrt{ } \mathrm{X} / 100$ function prior to ANOVA. The following mixed linear model was applied on an individual cutting basis to detect significant differences in mycorrhizal colonization among the clones and the bacterial treatment:

$$
\mathrm{Y}_{\mathrm{ijkl}}=\mu+\mathrm{B}_{\mathrm{i}}+\mathrm{G}_{\mathrm{j}}+\mathrm{T}_{1}+\varepsilon_{\mathrm{ijkl}}
$$

where, $\mu$ is the overall mean, B is the block effect (fixed), $G$ is the genotype effect (random), $\mathrm{T}$ is the bacterial treatment (random) and $\varepsilon$ is the random pooled residual error.

\section{RESULTS}

\section{BICOLOR MYCELIAL GROWTH AND ARCHITECTURE}

We carried out in vitro co-cultures of 23 Pseudomonas isolates and $L$. bicolor on which we measured the mycelium radial growth, apex number, branching angle and branching density. The radial growth of L. bicolor S238N was differentially influenced by these 23 Pseudomonas strains, including the two controls. Based on the wide array of growth effects on L. bicolor S238N, Pseudomonas strains were categorized into three classes-(1) no significant effect, (2) a significant negative effect, and (3) a significant positive effect (Figure 1, Table 1, Table S1). Indeed, compared to the control, strains GM16 and GM24 had no significant effects on fungal radial growth (Table S1). Alternatively, strains Pf5 and GM17 significantly inhibited Laccaria radial growth as early as $12 \mathrm{~d}$ of dual cultivation (Figure 1, Table 1, Table S1) at which point no contact between $L$. bicolor mycelium and bacterial colonies was observed. In contrast, the MHB strain BBc6R8 stimulates fungal growth at $12 \mathrm{~d}$ and $14 \mathrm{~d}$, as well as after contact (Figure 1, Table 1, Table S1). Strains GM18, GM21, GM25, GM30, GM33, GM41, GM48, GM49, GM50, GM55, GM60, GM67, GM74, GM78, GM79, GM80, GM84, and GM102 each stimulated L. bicolor growth after $16 \mathrm{~d}$ (Table 1, Table S1). Strains
GM41 and GM18 had the most significant effect on L. bicolor growth, habit and colony diameter throughout the experiment (Figure 1 and Table S1). Most of the above strains had a similar positive effect on apex number, branching angle and branching density (Table 1), though GM41 had a slightly higher enhancement of apex number. However, both GM41 and GM18 also increased hyphal branching angle and branching density. By contrast GM17 and Pf5 induced a high amount of curvature in the hyphae. Interestingly, hyphal branching density was higher with GM17 than with BBc6R8; hyphal branching density was considerably reduced in the presence of Pf-5.

\section{BICOLOR GENE EXPRESSION ANALYSIS}

We evaluated the expression of S238N genes (Figures S1, S2), Cipc1, Tectonin2, Fox2, Tra1, Gcn5, Spt3, and Ada3, which are known marker genes for $P$. fluorescens BBc6R8 interactions with L. bicolor (Deveau et al., 2007) at 14 DPI before Laccaria-bacteria contact and at $21 \mathrm{DPI}$ after extended contact. A wide variation in the expression of the seven Laccaria target genes was observed during co-cultivation experiments, before, as well as after, contact with the bacterial strains. However, strains GM17, GM33, GM41, GM48, Pf-5, and BBc6R8 consistently and significantly modified (i.e., some up-regulated and some down) the expression of Tra1, Tectonin2, Gcn5, and Cipc1 both before and after contact. We did not detect any significant change in expression in Ada3, Fox2, and $S p t 3$ across all bacterial strains at either time point (Figures $\mathrm{S} 1, \mathrm{~S} 2)$.

\section{BACTERIAL EFFECT ON POPULUS ROOT ARCHITECTURE}

The effect of bacterial strains BBc6R8, GM41, GM30, GM18, and GM17 in the presence of L. bicolor S238N on the number and length of secondary roots across three Populus genotypes, "93-968," "717-1B4," and "D-124," was evaluated in vitro at 14 DPI and 31 DPI (Figures S2, S3). In the presence of Laccaria alone, and for plants growing with Laccaria-GM18, Laccaria-GM30, and Laccaria-GM41, the number of secondary roots is significantly higher than for plants growing axenically at 14 DPI and 31 DPI (Figures S2, S3). However, the

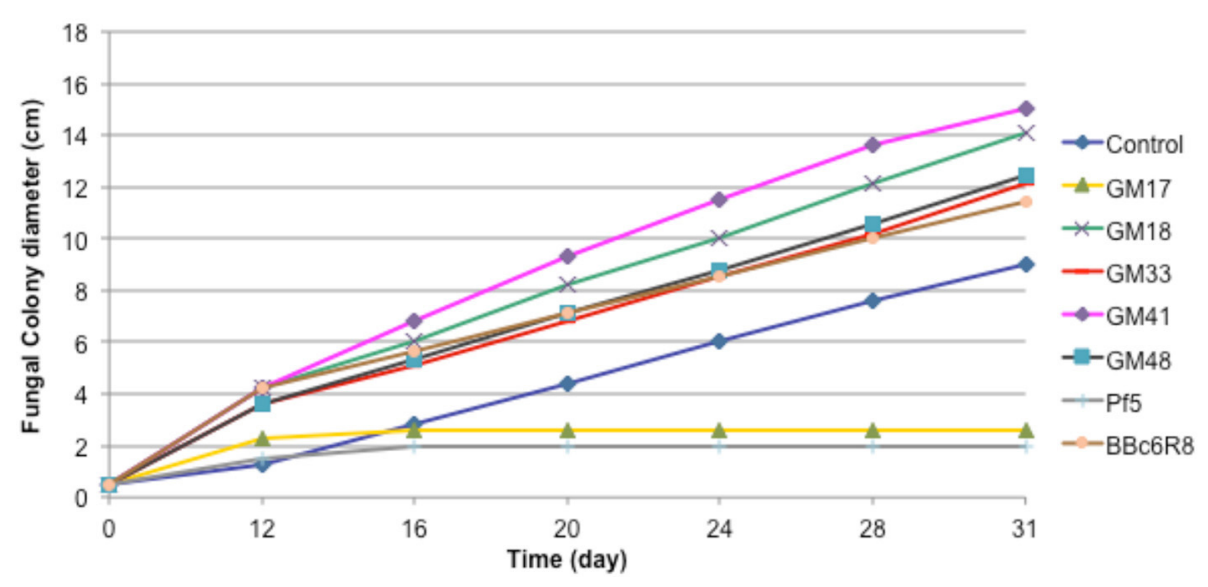

FIGURE 1 | Effect of seven Pseudomonas strains on radial growth of Laccaria bicolor S238N. Control: bacterial suspension was substituted by sterile deionized water. Each data point represents the mean $( \pm S E)$ of seven replicates. 


\section{Table 1 | Summary of the Pseudomonas strains effect on Laccaria bicolor S238N-mycelial growth, L. bicolor gene expression, and} mycorrhization of Populus roots.

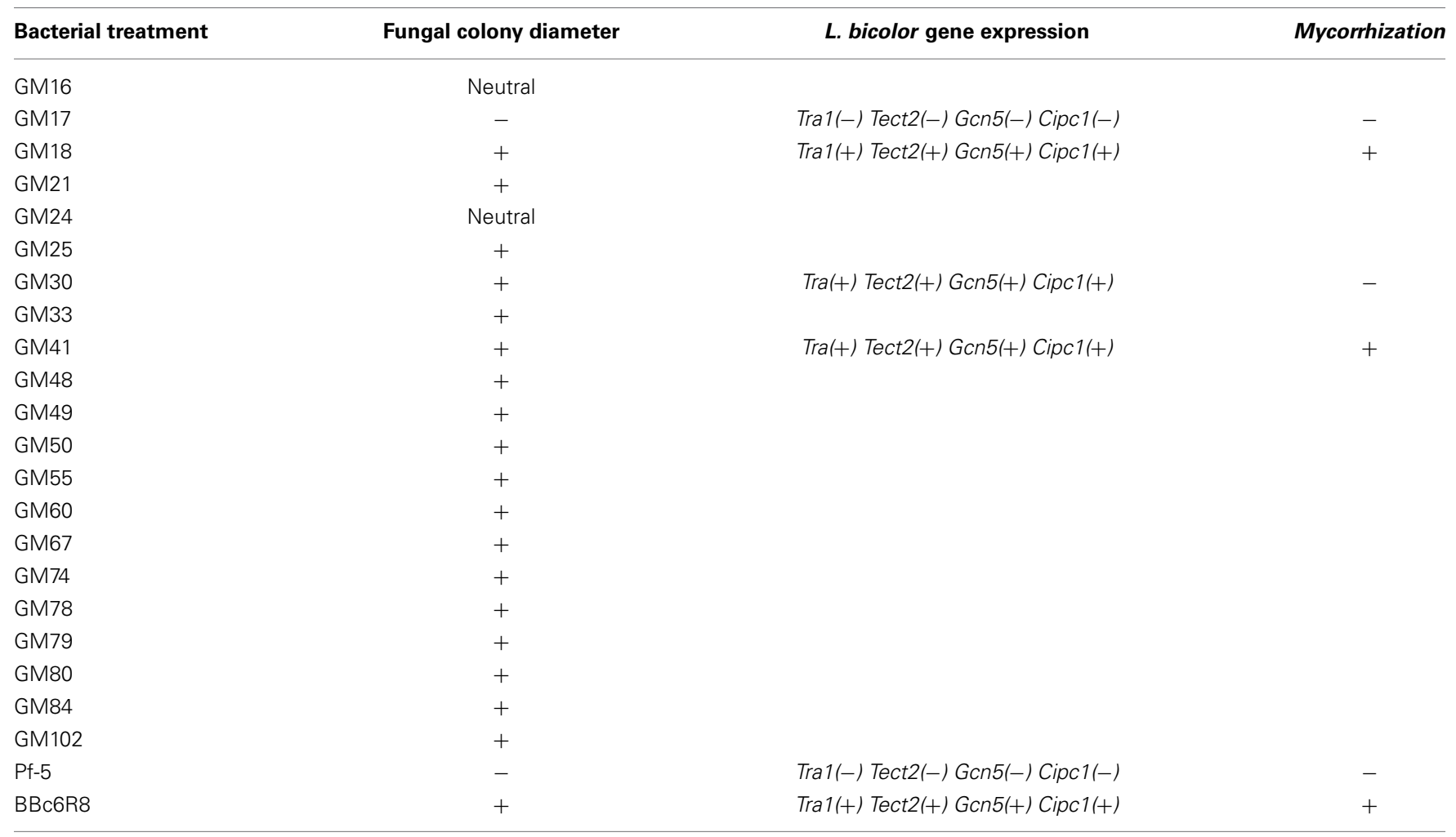

(+), up-regulated; (-), down-regulated.

three Populus genotypes in these three tripartite co-conditions have more secondary roots than plants treated by Laccaria alone. In fact, plants treated by Laccaria-GM41 produced more secondary roots than any other fungal-bacterial combinations (Figure 2). "D-124" plants have longer secondary roots when treated by Laccaria-GM30 than "93-968" and "717-1B4" (Figures S4, S5). ANOVA result showed consistent Populus genotype effects (Table 2).

\section{BACTERIAL EFFECT ON L. BICOLOR COLONIZATION OF POPULUS ROOTS}

Twelve weeks after inoculation, L. bicolor colonization of the plant root system was assessed. No colonization by potential contaminant was noticed either by microscopic observation or re-isolation experiments. The root systems of "93-968" clones (P. trichocarpa) were colonized with an average rate of $44 \pm 1 \%$, while "D-124" ( $P$. deltoides), and “717-1B4" ( $P$. tremula $\times$ alba) plants were colonized at $15 \pm 2 \%$ and $26 \pm 1 \%$, respectively (Table 2, Figure 3). Under bacterial treatment, "93-968" roots were the most efficiently colonized, followed by "717-1B4" and then "D-124." Across the three Populus genotypes, the highest Laccaria colonization rate occurred in combination with GM41. In contrast, GM30 and GM17 produced some of the lowest colonization rates, i.e., $9 \pm 2 \%$ (with GM30) and $3 \pm 2 \%$ (with GM17) with "93-968," and $5 \pm 2 \%$ (with GM30) and $1 \pm 2 \%$ (with GM17) with "717-1B4," while "D-124" was not colonized by Laccaria in combination with either GM17 or GM30.

\section{DISCUSSION}

Here we investigated the effect of 21 Pseudomonas strains, isolated from native $P$. deltoides rhizosphere, on L. bicolor growth, morphology and Populus root colonization in order to characterize MHB strain within the model system Populus-Laccaria. Our results demonstrate potential use of microbial component for improved root biomass production. The inferred data suggest that particular microbial combinations might determine which interactions can be exploited to enable inoculated plants to behave in a more competitive way and to survive when established in the field. This idea is supported by the work of Requena et al. (1997), in which Rhizobium strains from the rhizosphere of the legume Anthyllis cystoides was screened and combined with arbuscular mycorrhizal fungi. They highlighted that beneficial fungi where more effective in promoting plant growth when associated with rhizobacteria from the pool of native soil bacteria, which supposedly are adapted to the particular soil and climatic conditions of an area.

Deveau et al. (2007) previously demonstrated that P. fluorescens $\mathrm{BBc} 6 \mathrm{R} 8$ has a stimulating effect on L. bicolor $\mathrm{S} 238 \mathrm{~N}$ growth, hyphal branching angle and density and gene expression in an agar plate system. Here, we confirmed that strain BBc6R8 has such a helper effect on L. bicolor S238N. Additionally, we determined that 17 out of 21 Pseudomonas isolates (GM21, GM25, GM30, GM48, GM49, GM50, GM55, GM60, GM67, GM74, GM78, GM79, GM80, GM84 GM102, GM18, and GM41) have a positive effect on the growth of the same fungal strain. 
A Populus trichocarpa '93968'

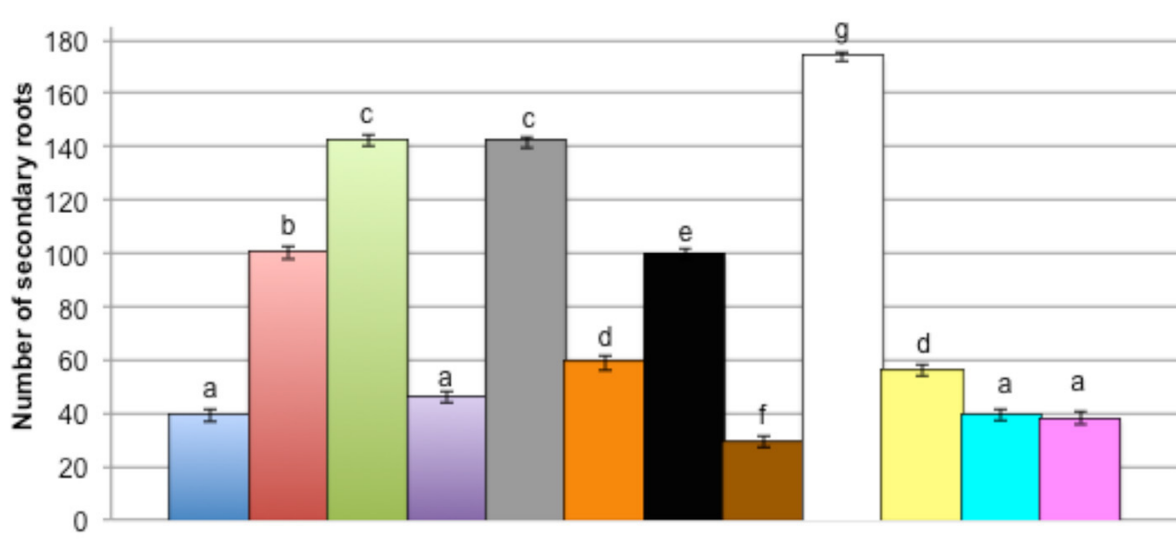

B P. deltoides 'D124'

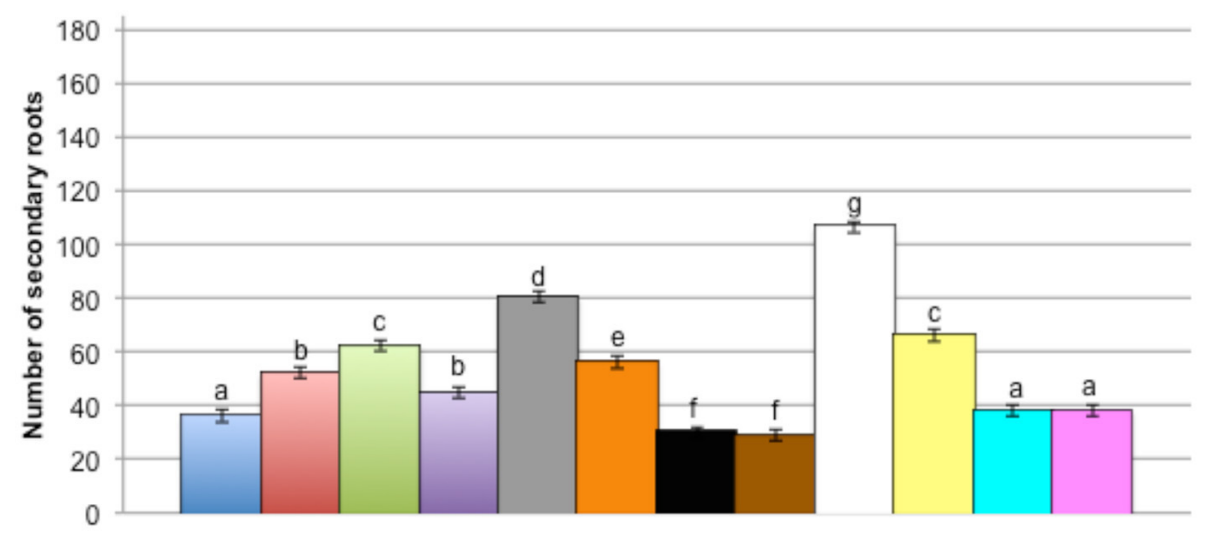

C P. tremula $\times$ P. alba ' $717^{\prime}$

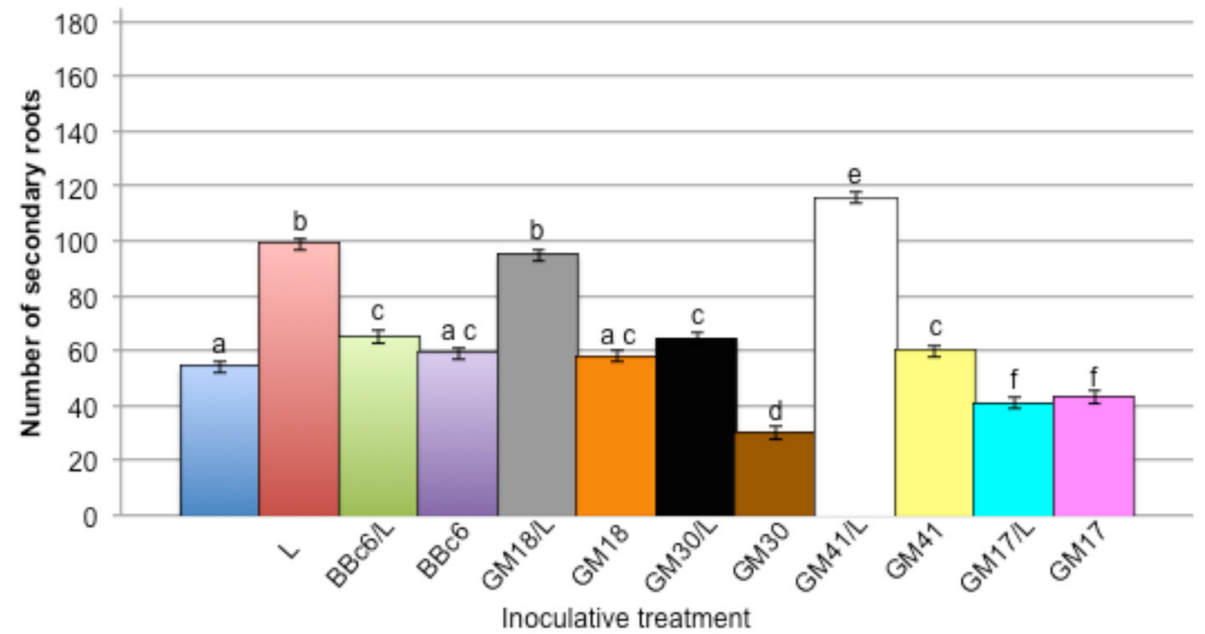

FIGURE 2 | Effect of Pseudomonas fluorescens strains BBc6R8, GM18, GM30, GM41, and GM17 on the number of secondary roots of Populus, 31 days post-inoculation (DPI). (A) Populus trichocarpa '93-968', (B) P. deltoides
'D-124' and (C) P. tremula x P. alba '717-1B4'. "L": Laccaria bicolor S238N. Bars with the same letters are not significantly different according to Tukey's HSD test. Error bars denote standard error.
Fifteen of the 21 bacterial isolates have a similar effect as BBc6R8 and two, GM18 and GM41, have a more pronounced effect on fungal growth. Similar to BBc6R8, we demonstrated that GM18 and GM41 increase colony growth by increasing hyphal density via hyphal branching. Enhanced hyphal branching represents a potential mechanism that could lead to increased colonization of plant roots by ectomycorrhizal fungi. Aspray et al. (2013) have suggested that $P$. fluorescens strains might be able to produce 
branching factor(s) as reported in the MHB Paenibacillus spp. EJP73. Unexpectedly, we observed a simultaneous increase in mycelium growth and density, suggesting that the mechanism and molecular regulators may differ. We also report a negative effect on L. bicolor S238N growth in combination with strain GM17 as well as for the biocontrol strain Pf-5. We observed the production of phenazine crystals in GM17 culture (Ovchinnikova et al., 2014), which has been shown to provide biocontrol through antimicrobial activity (Shanmugaiah et al., 2010). Interestingly, GM17 produced reduced-radial colony growth and increased branching density of L. bicolor similar to that reported by Aspray et al. (2013) for Paenibacillus sp. EJP73 and Lactarius rufus. Schrey et al. (2007) also demonstrated that the mycorrhiza helper bacterium Streptomyces spp. AcH 505 with the ectomycorrhizal fungus Amanita muscaria reduces the hyphal diameter. Compounds released by the bacterium into the growth medium were sufficient to induce these changes. Furthermore, the promoted growth rate and reduced diameter of hyphae are associated with a high frequency of hyphal tips with reorganized actin cytoskeleton. Schrey et al. (2007) suggest that bacterial compounds modulate the actin organization in the hyphal tip region, which could in turn induce the morphological changes. Hence, the resulting enhanced hyphal growth might be an important factor behind the mycorrhiza helper effect exhibited by some MHB.

Table 2 | ANOVA results for the percentage of mycorrhizal colonization (\%Myc) in three Populus genotypes: Populus deltoides “D-124," P. trichocarpa "93-968," and P. tremula x P. alba "717-1B4."

\begin{tabular}{ccclc}
\hline Trait & Effect & df & F-value & $\boldsymbol{P}$ \\
\hline \% Myc & Genotype & 2 & 5.26 & 0.0001 \\
& Bacterial treatment & 4 & 3.38 & 0.2354 \\
& Block & 7 & 0.2975 & 0.3456 \\
\hline
\end{tabular}

a Pooled error was used as the denominator in all F-tests.
We confirmed the responsiveness of the L. bicolor $\mathrm{S} 238 \mathrm{~N}$ genes Cipc1, Tectonin2, Fox2, Tra1, Gcn5, Spt3, and Ada3 upon cocultivation with tested Pseudomonas isolates, including the known MHB strain BBc6R8. Despite wide variation in gene expression levels across the bacterial strains, we were able to demonstrate significant changes ( $<$ or $>2$-fold) in expression for Tra1, Tectonin2, Gcn5, and Cipc1, before and after contact with GM17, GM33, GM41, GM48, Pf-5, and BBc6R8. Given that these gene expression patterns appear to be shared across the Pseudomonas strains, and not specific to the L. bicolor S238N-BBc6R8 interaction, we propose that these genes could be considered as marker/reporter genes of L. bicolor S238N-P. fluorescens interactions.

The predicted function of each of these genes varies. For example, Tral is known to be involved in transcriptional regulatory complexes (SAGA, SALSA) in yeast (Wu et al., 2004), suggesting that chromatin structure modifications take place in L. bicolor $\mathrm{S} 238 \mathrm{~N}$ in response to Pseudomonas. A similar mechanism can be proposed for Gcn5 (the SAGA complex: Spt-AdaGcn5-acetyltransferase). Tectonin 2 codes for a protein known to participate in bacterial cell aggregation during phagocytosis by amoebae cells (Huh et al., 1998) and could play a role in cell recognition and/or fungal cell interaction with Pseudomonas. As reported by Deveau et al. (2007), Cipcl appears to be linked to the modification of L. bicolor growth and morphology and could therefore be considered a marker of induction of the presymbiotic status of the fungus (opposed to the alternate saprobe status of the exploring mycelium). In support of these putative roles, we observed that with the biocontrol strains GM17 and Pf-5 there was a down-regulation of all four genes, Tra1, Tectonin2, Gcn5, and Cipc1, and an associated negative effect on fungal growth. Finally, we noticed the strongest effect on fungal radial growth from strains GM41 and GM18. These two bacterial isolates had a wide variation on the expression level of Tra1, Tectonin2, and Gcn5, suggesting that gene induction may not be quantitatively linked to the highest phenotypic effect and that there may be a potential role for post-transcriptional regulation

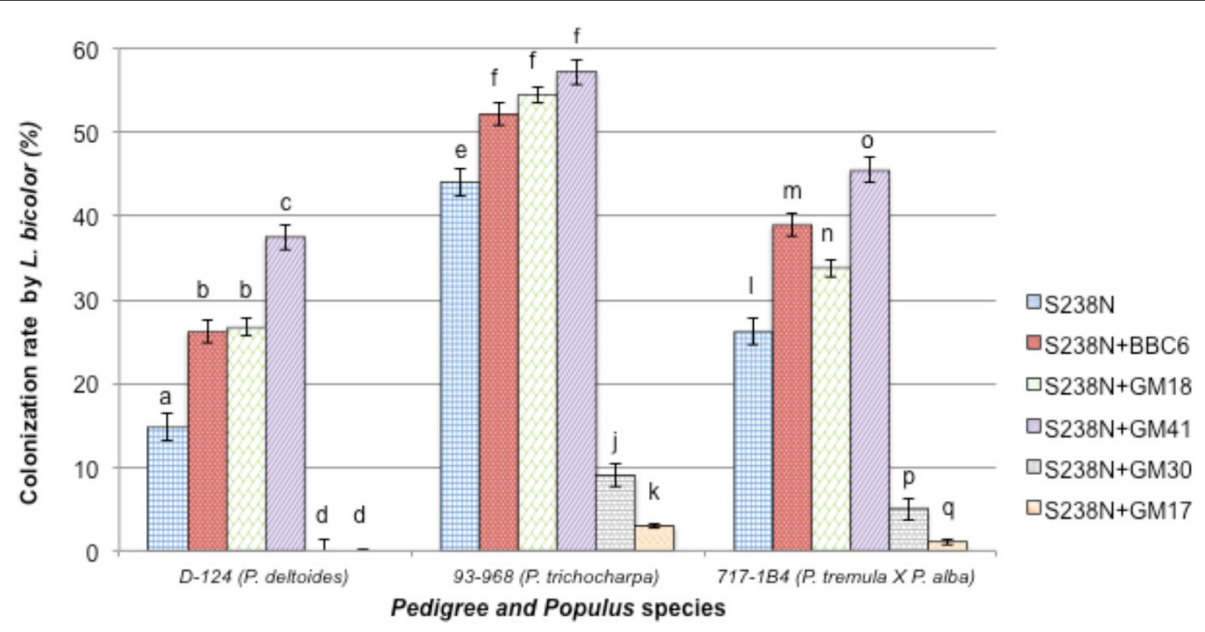

FIGURE 3 | Percentage of roots from three Populus genotypes colonized by Laccaria bicolor S238N in co-culture with Pseudomonas fluorescens strains BBc6R8, GM18, GM41, GM30, and GM17. Bars with the same letters are not significantly different according to Tukey's HSD test. Error bars denote standard error. 
during colonization and signal transduction. Further investigation will be needed to confirm this gene expression to phenotype relationship.

We next examined the effect of BBc6R8, GM17, GM18, GM30, and GM41 on in vitro root architecture (number and length of secondary roots) across three Populus genotypes representing alternate Populus species. We focused on four Pseudomonas isolates-GM17 because of its negative effect on Laccaria, GM30, and the GM18 because of the similar effect as BBc6R8 and GM41 because of its strong positive effect on the L. bicolor S238N growth. We have shown that BBc6R8, GM18, GM30, and GM41 significantly enhanced the number of secondary roots across all tested genotypes in the presence of L. bicolor S238N. Poole et al. (2001) reported that bacteria (Burkholderia and Pseudomonas) isolated from Pinus sylvestris_Lactarius rufus mycorrhizas did not affect the total number of roots formed by the plants but only ectomycorrhizal formation. While Bending et al. (2002) found bacteria isolates (Burkholderia spp., Serratia spp., Pseudomonas spp., and Bacillus spp.) from Pinus sylvestris-Suillus luteus mycorrhizas stimulating root growth and even shoot growth by Bacillus spp. but not ectomycorrhiza.

Bending et al. (2002) also demonstrated that Pseudomonas isolates stimulated lateral root formation similar to our results. In total, these results suggest a diversity of growth promoting mechanisms operating on plant or fungi and/or both and illustrate the complexity of the evolving MHB concept.

The lack of $S 238 \mathrm{~N}$ colonization of $P$. deltoides roots and the low colonization rates of the two other Populus genotypes observed in tripartite combinations with strain GM30 in the greenhouse was unexpected, given that in the in vitro studies GM30 had a beneficial effect on L. bicolor or Populus growth in binary combinations. Bending et al. (2002) have reported similar observations and showed that several bacterial isolates enhanced plant growth substantially, although these effects were unrelated to either root colonization by the fungus or ectomycorrhiza formation. Comparative variation in P. trichocarpa and P. deltoides colonization by L. bicolor, with $P$. trichocarpa obtaining higher colonization rates, and as previously observed in several studies (Tagu et al., 2005; Labbé et al., 2011), remained generally consistent across bacterial treatments. That is, strains BBc6R8, GM18, and GM41 enhanced colonization yield in both P. trichocarpa and $P$. deltoides in relative abundance, interestingly GM41 increased the colonization rate of $P$. deltoides by 2.5 fold.

Labbé et al. (2011) has suggested that the activation of defense mechanisms in $P$. deltoides may inhibit L. bicolor colonization, while in $P$. trichocarpa defense mechanisms are ultimately repressed. Similarly, Garbaye (1994) suggested that a mycorrhiza helper bacterium could increase the rate of plant root colonization by positively affecting "root receptivity." Lehr et al. (2006) reported such an observation with AcH505, which suppresses defense response in Norway spruce (Picea abies) allowing colonization by Heterobasidion annosum. We propose that the tested Pseudomonas strains might play a similar role with a variety of responses.

With respect to bacterial strain origins, BBc6R8 was isolated from a sporocarp of L. bicolor S238N associated with Douglasfir roots (Duponnois and Garbaye, 1991) while strains GM18 and GM41 were isolated from roots of native P. deltoides (Gottel et al., 2011). Each of these strains improved the L. bicolor S238N colonization of $P$. deltoides. However, strain GM41 produced significantly higher $L$. bicolor colonization of $P$. deltoides and might potentially be recruited by $P$. deltoides and may have co-evolved within Laccaria bicolor and Populus deltoides system. Duponnois et al. (1993) have suggested the high fungal specificity of MHB is controlled by the bacterial and fungal relationship and not the tree species. Our work suggests that the Laccaria-MHB interactions are not as specific as believed, at least at the isolate level. This is in accordance with Founoune et al. (2002a) work in which bacterial inoculant has been used in Australian Acacia species and with their mycorrhizal associates.

To date, most MHB reports have investigated the behavior of fungal mycelium correlated with efficiency of mycorrhiza formation (Garbaye and Duponnois, 1993; Frey-Klett et al., 1997; Poole et al., 2001; Founoune et al., 2002a). As suggested by Garbaye (1994), the mycorrhizal helper effect could include increased receptivity of roots to fungal hyphae or improved fungal colonization of fine roots due to plant cell wall modifying bacterial substances. In general our MHB strains that stimulated mycelial growth and mycorrhiza formation also acted as plant growth promoters (i.e., increased root branching) suggesting auxin-like activity. Production of auxin or indole-acetic acid (IAA) is known to be widespread among rhizosphere bacteria and is one of the major marker genes by which the beneficial effect of plantpromoting bacteria is measured (Glick, 1995). Auxin production has been previously reported in BBc6R8 (Frey-Klett et al., 2007) and we have detected auxin production in our Pseudomonas strains (data not shown). L. bicolor $\mathrm{S} 238 \mathrm{~N}$ also stimulates lateral Populus root production via fungal auxin and volatile molecules (Felten et al., 2010). It is reasonable to speculate that enhanced lateral root formation in response to beneficial microbes may be a conserved mechanism that soil microbes employ for their own benefit in order to enhance root exudation and thus increase the energy flow from the roots of host plants.

Although it has been suggested that the predominant mechanism to describe the mycorrhizal helper effect is the positive effect on fungal metabolism and morphology, MHB could also promote plant growth, in contrast to Duponnois et al. (1993). In the case of stimulation of L. bicolor mycorrhiza formation on Douglas-fir by $\mathrm{BBc} 6 \mathrm{R} 8$, fungus growth was found to be inhibited as the bacterial inoculum increased, so that low doses were the most stimulatory to the fungus (Frey-klett et al., 1999). As Bending et al. (2002) have suggested, characterizing the spatial distribution and size of bacterial communities within the rhizosphere will be required to determine the nature and extent of bacterial effects on mycorrhiza formation and plant growth.

In conclusion, we report that MHB strains isolated from native Populus rhizosphere samples have strong benefits on $L$. bicolor growth and root colonization of Populus trees. This study reflects results mainly obtained from in vitro and greenhouse experiments. Further investigations are needed to explore whether these systems behave similarly in nursery and/or field studies. This work emphasizes the importance of studying MHB since plantfungal interactions can be strongly influenced by MHB and may therefore be key players in determining rhizosphere diversity and 
thus a molecular level of understanding is necessary engineering a sustainable environment.

\section{ACKNOWLEDGMENTS}

We thank Drs. P. Frey-Klett, A. Deveau for their help and fruitful discussions. This work was supported by the PlantMicrobe Interfaces Scientific Focus Area project at Oak Ridge National Laboratory (ORNL) sponsored by Office of Biological and Environmental Research at the United States Department of Energy Office of Science. ORNL is managed by UT-Battelle, LLC, under contract DE-AC05-00OR22725 for the United States Department of Energy.

\section{SUPPLEMENTARY MATERIAL}

The Supplementary Material for this article can be found online at: http://www.frontiersin.org/journal/10.3389/fpls.2014.00579/ abstract

\section{REFERENCES}

Artursson, V., Finlay, R. D., and Jansson, J. K. (2006). Interactions between arbuscular mycorrhizal fungi and bacteria and their potential for stimulating plant growth. Environ. Microbiol. 8, 1-10. doi: 10.1111/j.1462-2920.2005.00942.x

Aspray, T. J., Jones, E. E., Davies, M. W., Shipman, M., and Bending, G. D. (2013). Increased hyphal branching and growth of ectomycorrhizal fungus Lactarius rufus by the helper bacterium Paenibacillus sp. Mycorrhiza 23, 403-410. doi: 10.1007/s00572-013-0483-1

Barea, J. M., Andrade, G., Bianciotto, V., Dowling, D., Lohrke, S., Bonfante, P., et al. (1998). Impact on arbuscular mycorrhiza formation of Pseudomonas strains used as inoculants for biocontrol of soil-borne fungal plant pathogens. Appl. Environ. Microbiol. 64, 2304-2307.

Barea, J.-M., Azcón, R., Azcón-Aguilar, C., Barea, M., and Azc, R. (2002). Mycorrhizosphere interactions to improve plant fitness and soil quality. Antonie Van Leeuwenhoek 81, 343-351. doi: 10.1023/A:1020588701325

Becker, D. M., Bagley, S. T., and Podila, G. K. (1999). Effects of MycorrhizalAssociated Streptomycetes on Growth of Laccaria bicolor, Cenococcum geophilum, and Armillaria Species and on gene expression in Laccaria bicolor. Mycologia 91, 33. doi: 10.2307/3761191

Bending, G. D., Poole, E. J., Whipps, J. M., and Read, D. J. (2002). Characterisation of bacteria from Pinus sylvestris-Suillus luteus mycorrhizas and their effects on root-fungus interactions and plant growth. FEMS Microbiol. Ecol. 39, 219-227. doi: 10.1111/j.1574-6941.2002.tb00924.x

Bradshaw, H. D. D., Ceulemans, R., Davis, J., and Stettler, R. (2000). Emerging model systems in plant biology: poplar (Populus) as a model forest tree. J. Plant Growth Regul. 19, 306-313. doi: 10.1007/s003440000030

Brown, S. D., Utturkar, S. M., Klingeman, D. M., Johnson, C. M., Martin, S. L., Land, M. L., et al. (2012). Twenty-one genome sequences from Pseudomonas species and 19 genome sequences from diverse bacteria isolated from the rhizosphere and endosphere of Populus deltoides. J. Bacteriol. 194, 5991-5993. doi: 10.1128/JB.01243-12

Budi, S. W., van Tuinen, D., Martinotti, G., Gianinazzi, S., and Van Tuinen, D. (1999). Isolation from the Sorghum bicolor mycorrhizosphere of a bacterium compatible with arbuscular mycorrhiza development and antagonistic towards soilborne fungal pathogens. Appl. Environ. Microbiol. 65, 5148-5150.

Deveau, A., Palin, B., Delaruelle, C., Peter, M., Kohler, A., Pierrat, J. C., et al. (2007). The mycorrhiza helper Pseudomonas fluorescens BBc6R8 has a specific priming effect on the growth, morphology and gene expression of the ectomycorrhizal fungus Laccaria bicolor S238N. New Phytol. 175, 743-755. doi: 10.1111/j.14698137.2007.02148.x

Di Battista, C., Selosse, M.-A., Bouchard, D., Stenström, E., and Le Tacon, F. (1996). Variations in symbiotic efficiency, phenotypic characters and ploidy level among different isolates of the ectomycorrhizal basidiomycete Laccaria bicolor strain S238. Mycol. Res. 100, 1315-1324. doi: 10.1016/S0953-7562(96)80058-X

Duponnois, R. (2006). "Bacteria helping mycorrhiza development," in Microbial Activity in the Rhizosphere, eds K. G. Mukerji, C. Manoharachary, and J. Singh (Berlin; Heidelberg: Springer-Verlag), 297-310.
Duponnois, R., and Garbaye, J. (1991). Effect of dual inoculation of Douglas-fir with the ectomycorrhizal fungus Laccaria laccata and mycorrhization helper bacteria (MHB) in two bare-root forest nurseries. Plant Soil 138, 169-176. doi: 10.1007/BF00012243

Duponnois, R., Garbaye, J., Bouchard, D., and Churin, J. L. (1993). Fungusspecificity of mycorrhization helper bacteria (MHBs) used as an alternative to soil fumigation for ectomycorrhizal inoculation of bare-root Douglas-fir planting. Plant Soil 157, 257-262. doi: 10.1007/BF00011054

Duponnois, R., and Kisa, M. (2006). The possible role of trehalose in the mycorrhiza helper bacterium effect. Can. J. Bot. 84, 1005-1008. doi: 10.1139/ b06-053

Felten, J., Legué, V., and Ditengou, F. A. (2010). Lateral root stimulation in the early interaction between Arabidopsis thaliana and the ectomycorrhizal fungus Laccaria bicolor: is fungal auxin the trigger? Plant Signal. Behav. 5, 864-867. doi: 10.4161/psb.5.7.11896

Founoune, H., Duponnois, R., and Ba, A. (2002a). Mycorrhiza helper bacteria stimulate ectomycorrhizal symbiosis of Acacia holosericea with Pisolithus alba. New Phytol. 153, 81-89. doi: 10.1046/j.0028-646X.2001. 00284.x

Founoune, H., Duponnois, R., Marie, J., Thioulouse, J., Masse, D., Luc, J., et al. (2002b). Interactions between ectomycorrhizal symbiosis and fluorescent pseudomonads on Acacia holosericea: isolation of mycorrhiza helper bacteria (MHB) from a Soudano-Sahelian soil. FEMS Microbiol. Ecol. 41, 37-46. doi: 10.1111/j.1574-6941.2002.tb00964.x

Frey-klett, P., Chavatte, M., Clausse, M.-L., Courrier, S., Roux, C., Le Raaijmakers, J. et al. (2005). Ectomycorrhizal symbiosis affects functional diversity of rhizosphere fluorescent pseudomonads. New Phytol. 165, 317-328. doi: 10.1111/j.1469-8137.2004.01212.x

Frey-klett, P., Churin, J.-L., Pierrat, J.-C., and Garbaye, J. (1999). Dose effect in the dual inoculation of an ectomycorrhizal fungus and a mycorrhiza helper bacterium in two forest nurseries. Soil Biol. Biochem. 31, 1555-1562. doi: 10.1016/S0038-0717(99)00079-6

Frey-Klett, P., Garbaye, J., and Tarkka, M. (2007). The mycorrhiza helper bacteria revisited. New Phytol. 176, 22-36. doi: 10.1111/j.1469-8137.2007.02191.x

Frey-Klett, P., Pierrat, J. C., and Garbaye, J. (1997). Location and survival of mycorrhiza helper Pseudomonas fluorescens during establishment of ectomycorrhizal symbiosis between Laccaria bicolor and Douglas-Fir. Appl. Environ. Microbiol. $63,139-144$.

Garbaye, J. (1994). Interactions between mycorrhizal fungi and other soil organisms. Plant Soil 159, 123-132.

Garbaye, J., and Duponnois, R. (1993). Specificity and function of mycorrhization helper bacteria (MHB) associated with the Pseudotsuga menziesii—Laccaria laccata symbiosis. Symbiosis 14, 335-344.

Glick, B. R. (1995). The enhancement of plant growth by free-living bacteria. Can. J. Microbiol. 41, 109-117. doi: 10.1139/m95-015

Gottel, N. R., Castro, H. F., Kerley, M., Yang, Z., Pelletier, D. A., Podar, M., et al. (2011). Distinct microbial communities within the endosphere and rhizosphere of Populus deltoides roots across contrasting soil types. Appl. Environ. Microbiol. 77, 5934-5944. doi: 10.1128/AEM.05255-11

Howell, C. R., and Stipanovic, R. D. (1978). Control of Rhizoctonia solani on cotton seedlings with Pseudomonas fluorescens and with an antibiotic produced by the bacterium by the soil tube method described previously. Phytopathology 69, 480-482. doi: 10.1094/Phyto-69-480

Huh, C. G., Aldrich, J., Mottahedeh, J., Kwon, H., Johnson, C., and Marsh, R. (1998). Cloning and characterization of Physarum polycephalum tectonins. Homologues of Limulus lectin L-6. J. Biol. Chem. 273, 6565-6574. doi: $10.1074 /$ jbc.273.11.6565

Jansson, S., and Douglas, C. J. (2007). Populus: a model system for plant biology. Annu. Rev. Plant Biol. 58, 435-458. doi: 10.1146/annurev.arplant.58.032806. 103956

Johannsson, J. F., Paul, L. R., and Finlay, R. D. (2004). Microbial interactions in the mycorrhizosphere and their significance for sustainable agriculture. FEMS Microbiol. Ecol. 48, 1-13. doi: 10.1016/j.femsec.2003.11.012

Kang, B. G., Osburn, L., Kopsell, D., Tuskan, G. A., and Cheng, Z. M. (2009). Micropropagation of Populus trichocarpa "Nisqually-1": the genotype deriving the Populus reference genome. Plant Cell Tissue Organ Cult. 99, 251-257. doi: 10.1007/s11240-009-9596-9

Labbé, J., Jorge, V., Kohler, A., Vion, P., Marçais, B., Bastien, C., et al. (2011). Identification of quantitative trait loci affecting ectomycorrhizal symbiosis in an 
interspecific F1 poplar cross and differential expression of genes in ectomycorrhizas of the two parents: Populus deltoides and Populus trichocarpa. Tree Genet. Genomes 7, 617-627. doi: 10.1007/s11295-010-0361-3

Lehr, N. A., Schrey, S. D., Bauer, R., Hampp, R., and Tarkka, M. T. (2006). Suppression of plant defence response by a mycorrhiza helper bacterium. New Phytol. 174, 892-903. doi: 10.1111/j.1469-8137.2007.02021.x

Livak, K. J., and Schmittgen, T. D. (2001). Analysis of relative gene expression data using real-time quantitative PCR and the $2(\Delta \Delta \mathrm{CT})$ Method. Methods 25, 402-408. doi: 10.1006/meth.2001.1262

Loper, J. E., Kobayashi, D. Y., and Paulsen, I. T. (2007). The genomic sequence of pseudomonas fluorescens Pf-5: insights into biological control. Phytopathology 97, 233-238. doi: 10.1094/PHYTO-97-2-0233

Martin, F., Aerts, A., Ahrén, D., Brun, A., Danchin, E. G. J., Duchaussoy, F., et al. (2008). The genome of Laccaria bicolor provides insights into mycorrhizal symbiosis. Nature 452, 88-92. doi: 10.1038/nature06556

Martin, F., Tuskan, G. A., DiFazio, S. P., Lammers, P., Newcombe, G., and Podila, G. K. (2004). Symbiotic sequencing for the Populus mesocosm. New Phytol. 161, 330-335. doi: 10.1111/j.1469-8137.2004.00982.x

Moore, F. P., Barac, T., Borremans, B., Oeyen, L., Vangronsveld, J., van der Lelie, D., et al. (2006). Endophytic bacterial diversity in poplar trees growing on a BTEX-contaminated site: the characterization of isolates with potential to enhance phytoremediation. Syst. Appl. Microbiol. 29, 539-556. doi: 10.1016/j.syapm.2005.11.012

Ovchinnikova, O. S., Kjoller, K., Hurst, G. B., Pelletier, D. A., and Van Berkel, G. J. (2014). Atomic force microscope controlled topographical imaging and proximal probe thermal desorption/ionization mass spectrometry imaging. Anal. Chem. 86, 1083-1090. doi: 10.1021/ac4026576

Paulsen, I. T., Press, C. M., Ravel, J., Kobayashi, D. Y., Myers, G. S. A., Mavrodi, D. V., et al. (2005). Complete genome sequence of the plant commensal Pseudomonas fluorescens Pf-5. Nat. Biotechnol. 23, 873-878. doi: 10.1038/nbt1110

Pivato, B., Offre, P., Marchelli, S., Barbonaglia, B., Mougel, C., Lemanceau, P., et al. (2009). Bacterial effects on arbuscular mycorrhizal fungi and mycorrhiza development as influenced by the bacteria, fungi, and host plant. Mycorrhiza 19, 81-90. doi: 10.1007/s00572-008-0205-2

Poole, E. J., Bending, G. D., Whipps, J. M., and Read, D. J. (2001). Bacteria associated with Pinus sylvestris-Lactarius rufus ectomycorrhizas and their effects on mycorrhiza formation in vitro. New Phytol. 151, 743-751. doi: 10.1046/j.0028646x.2001.00219.x

Read, D. J., Duckett, J. G., Francis, R., Ligrone, R., and Russell, A. (2000). Symbiotic fungal associations in 'lower'land plants. Philo. Trans. R. Soc. Lond. Ser. B Biol. Sci. 355, 815-831. doi: 10.1098/rstb.2000.0617

Requena, N., Jimenez, I., Toro, M., and Barea, J. (1997). Interactions between plant-growth-promoting rhizobacteria (PGPR), arbuscular mycorrhizal fungi and Rhizobium spp. in the rhizosphere of Anthyllis cytisoides, a model legume for revegetation in Mediterranean semi-arid ecosystems. New Phytol. 136, 667-677. doi: 10.1046/j.1469-8137.1997.00786.x

Sambrook, J., Fritsch, E. F., and Maniatis, T. (1989). Molecular Cloning: A Laboratory Manual. New York, NY: Cold Spring Harbor Laboratory Press. 65-73.

Sannigrahi, P., and Ragauskas, A. J. (2010). Poplar as a feedstock for biofuels: a review of compositional characteristics. Biofuels Bioproducts Biorefining 4 209-226. doi: 10.1002/bbb.206

Schrey, S. D., Salo, V., Raudaskoski, M., Hampp, R., Nehls, U., and Tarkka, M. T. (2007). Interaction with mycorrhiza helper bacterium Streptomyces sp. AcH
505 modifies organisation of actin cytoskeleton in the ectomycorrhizal fungus Amanita muscaria (fly agaric). Curr. Genet. 52, 77-85. doi: 10.1007/s00294-0070138-x

Schrey, S. D., Schellhammer, M., Ecke, M., Hampp, R., and Tarkka, M. T. (2005). Mycorrhiza helper bacterium Streptomyces AcH 505 induces differential gene expression in the ectomycorrhizal fungus Amanita muscaria. New Phytol. 168, 205-216. doi: 10.1111/j.1469-8137.2005.01518.x

Shanmugaiah, V., Mathivanan, N., and Varghese, B. (2010). Purification, crystal structure and antimicrobial activity of phenazine-1-carboxamide produced by a growth-promoting biocontrol bacterium, Pseudomonas aeruginosa MML2212. J. Appl. Microbiol. 108, 703-711. doi: 10.1111/j.1365-2672.2009.04466.x

Taghavi, S., Lelie, D., Van Der Hoffman, A., Zhang, Y., and Walla, M. D. (2010). Genome sequence of the plant growth promoting endophytic bacterium Enterobacter sp. 638. PLoS Genet. 6:e1000943. doi: 10.1371/journal.pgen. 1000943

Tagu, D., Bastien, C., Faivre-Rampant, P., Garbaye, J., Vion, P., Villar, M., et al. (2005). Genetic analysis of phenotypic variation for ectomycorrhiza formation in an interspecific F1 poplar full-sib family. Mycorrhiza 15, 87-91. doi: 10.1007/s00572-004-0302-9

Tuskan, G. A., DiFazio, S., Jansson, S., Bohlmann, J., Grigoriev, I., Hellsten, et al. (2006). The genome of black cottonwood, Populus trichocarpa (Torr. \& Gray). Science 313, 1596-1604. doi: 10.1126/science.1128691

Tuskan, G. A., and Walsh, M. E. (2001). Short-rotation woody crop systems, atmospheric carbon dioxide and carbon management: a US case study. For. Chron. 77, 259-264. doi: 10.5558/tfc77259-2

Weisburg, W. G., Barns, S. M., Pelletier, D. A., and Lane, D. J. (1991). 16S ribosomal DNA amplification for phylogenetic study. J. Bacteriol. 173, 697-703.

Weston, D. J., Pelletier, D. A., Morrell-Falvey, J. L., Tschaplinski, T. J., Jawdy, S. S., Lu, T., et al. (2012). Pseudomonas fluorescens induces strain-dependent and strainindependent host plant responses in defense networks, primary metabolism, photosynthesis, and fitness. Mol. Plant Microbe Interact. 25, 765-778. doi: 10.1094/MPMI-09-11-0253

Wu, J., Zhang, N., Hayes, A., Panoutsopoulou, K., and Oliver, S. G. (2004). Global analysis of nutrient control of gene expression in Saccharomyces cerevisiae during growth and starvation. Proc. Natl. Acad. Sci. U.S.A. 101, 3148-3153. doi: $10.1073 /$ pnas. 0308321100

Conflict of Interest Statement: The authors declare that the research was conducted in the absence of any commercial or financial relationships that could be construed as a potential conflict of interest.

Received: 14 August 2014; accepted: 08 October 2014; published online: 24 October 2014.

Citation: Labbé JL, Weston DJ, Dunkirk N, Pelletier DA and Tuskan GA (2014) Newly identified helper bacteria stimulate ectomycorrhizal formation in Populus. Front. Plant Sci. 5:579. doi: 10.3389/fpls.2014.00579

This article was submitted to Plant-Microbe Interaction, a section of the journal Frontiers in Plant Science.

Copyright () 2014 Labbé, Weston, Dunkirk, Pelletier and Tuskan. This is an openaccess article distributed under the terms of the Creative Commons Attribution License (CC BY). The use, distribution or reproduction in other forums is permitted, provided the original author(s) or licensor are credited and that the original publication in this journal is cited, in accordance with accepted academic practice. No use, distribution or reproduction is permitted which does not comply with these terms. 